\title{
EJEMPLARIDAD, PATERNALISMO Y UTILITARIS- MO EN LA JUSTICIA DE LA ESPAÑA DE LOS HABSBURGO
}

\author{
José Luis DE LAS HERAS SANTOS \\ Universidad de Salamanca
}

Recibido: 28/04/2013

Aceptado: 04/11/2013

RESUMEN: El reconocimiento de privilegios en la sociedad del Antiguo Régimen obligó a dar a cada persona un trato diferenciado en los tribunales de justicia y a imponer penas distintas a nobles y a plebeyos. Por otra parte, las aspiraciones hegemonistas de la dinastía de los Habsburgo en Europa les obligó a guerrear continuamente contra sus adversarios y a concebir una idea muy utilitaria de la administración de justicia y de la penalidad.

Sobre la penalidad de los Habsburgo existen en España visiones muy contradictorias. Si atendemos a las penas previstas en el derecho y a las sentencias pronunciadas por los tribunales sacaremos una visión terrorífica del sistema judicial. Por el contrario, si nos quedamos con las fuentes que nos refieren la existencia de prácticas muy frecuentes de composiciones y acuerdos al margen del sistema judicial, obtendremos una visión edulcorada de la justicia, la cual toleraba límites de impunidad bastante elevados, sobre todo en la Corona de Aragón.

En realidad ambas cosas son ciertas. El margen de arbitrio concedido a los jueces permitía una represión cruel de los delitos, eventualmente atemperada por el paternalismo atribuido a la corona y por el hecho de que primaba la actuación a petición de parte sobre la actuación de oficio, lo que permitía en una sociedad con presencia de redes clientelares profundas y extensas, resolver muchos litigios fuera del ámbito judicial.

Hubo una impunidad asociada a las limitaciones de la administración de justicia en la época y otra relacionada con la existencia de componendas extrajudiciales sostenidas por el mutuo interés de las partes. Este fenómeno existió también en otros países europeos; pero, al menos en el ámbito hispánico, no debe interpretarse a priori como una manifestación de desconfianza de los súbditos en la justicia oficial. Aunque no podemos cuantificar en estos momentos el porcentaje de composiciones particulares, se puede estimar que fue inferior al de países como Inglaterra.

PALABRAS CLAVE: Administración de justicia, justicia y perdón, justicia utilitaria, penas y delitos , España de los Austrias, siglos XVI y XVII, sistema carcelario, trabajos forzados.

ABSTRACT: Privileges recognition in the Ancient Regime forced to give a different treatment to each person in the Courts of Justice and to set different penalties to nobles and commoners. On the other hand, the hegemonic aspirations of the Habsburg dynasty in Europe continually forced them to war against their enemies and to conceive an utilitarian idea of the administration of justice and penalty.

There are very contradictory ideas about Habsburgs's penalty in Spain. By looking at the penalties provided by the law and the judgements delivered by the courts, we get a terrifying sight of the judicial system. On the contrary, analysing the sources that refer to the existence of very frequent practices of compositions and arrangements outside the court system, we get a pleasant view of justice, which was quite tolerant with the limits of impunity, especially in the Crown of Aragon. And in fact both are true. The discretion margin conceded to judges allowed a cruel repression of crime, eventually moderated 
because of the paternalism attributed to the crown, and also because the individual action took priority over the court-appointed action, enabling -in a society where there was deep and extensive patronage networks- to resolve many disputes out of court.

There were impunity limitations associated with the administration of justice and another related to the existence of extra-judicial compromise supported by the mutual interest of the parties. This case also existed in other European countries, but, at least in the Hispanic sphere, it should not be interpreted as a display of distrust of subjects in the official justice. Although we cannot quantify the percentage of individual compositions at the moment, we can estimate that it was lower than in countries like England.

KEYWORDS: Administration of justice, justice and forgiveness, utilitarian justice, penalties and offenses, Habsburg Spain, sixteenth and seventeenth centuries, prison system, forced labor.

\section{EL CONTEXTO SOCIO-POLÍTICO DE LA ÉPOCA: UNA SOCIEDAD ESTAMENTAL, CON UNA MONARQUÍA ABSOLUTA SITUADA EN EL CENTRO DEL SISTEMA POLÍTICO Y JUDICIAL, EN LA QUE PRIMABAN LAS RELACIONES CLIENTELARES, LOS PRIVILEGIOS Y LA VIOLENCIA COTIDIANA}

Entre la sociedad del tiempo de los Habsburgo y la justicia que se administraba en su nombre existió un alto grado de correlatividad. Es sabido que desde el punto de vista jurídico la característica más señalada de la sociedad del Antiguo Régimen es la existencia de tres estamentos diferenciados unívocamente: La Nobleza, el Clero y el Tercer Estado. Los dos primeros estamentos eran privilegiados en el sentido etimológico de la palabra, gozaban de un tratamiento legal privativo, netamente favorable para ellos, distinto del ordenamiento general establecido para todos los demás súbditos. El privilegio es la antítesis del derecho. El privilegio se obtenía por concesión regia, y, al menos en teoría se podía revocar, mientras que un derecho es inherente.

Tanto los nobles como los eclesiásticos gozaban de un trato jurídico de favor: exención de pagar impuestos, etc. Los clérigos disponían de jurisdicción privativa. No así los nobles, pero en todo caso éstos constituían la cumbre de la pirámide social y concentraban riquezas, honores y preeminencias. El hecho de ser juzgados en la jurisdicción ordinaria no quiere decir que no disfrutasen de importantes privilegios penales. Sus bienes eran inembargables, no podían ser ser torturados, tenían derecho a cárcel separada de los plebeyos, etc. Incluso en los casos que se hicieran acreedores de la pena capital, su aplicación era distinta. Los plebeyos morían en la horca, mientras los nobles eran degollados. Es posible que para nosotros esta distinción parezca sutil, que no entendamos la ventaja de morir decapitados, previo seccionamiento de la yugular, sobre el estrangulamiento en el patíbulo. Tanto una muerte como la otra son terriblemente crueles y pueden provocar agonías inhumanas. 
En realidad no era muy importante si un tipo de muerte ocasionaba un poco más de sufrimiento que la otra. Lo verdaderamente relevante era que nobles y plebeyos eran distintos hasta en la ejecución de la pena capital.

\section{Ilustración 1. Ejecución de los Comuneros en Villalar. Antonio Gisbert, 1860. Fondos del Congreso de los Diputados, Madrid}

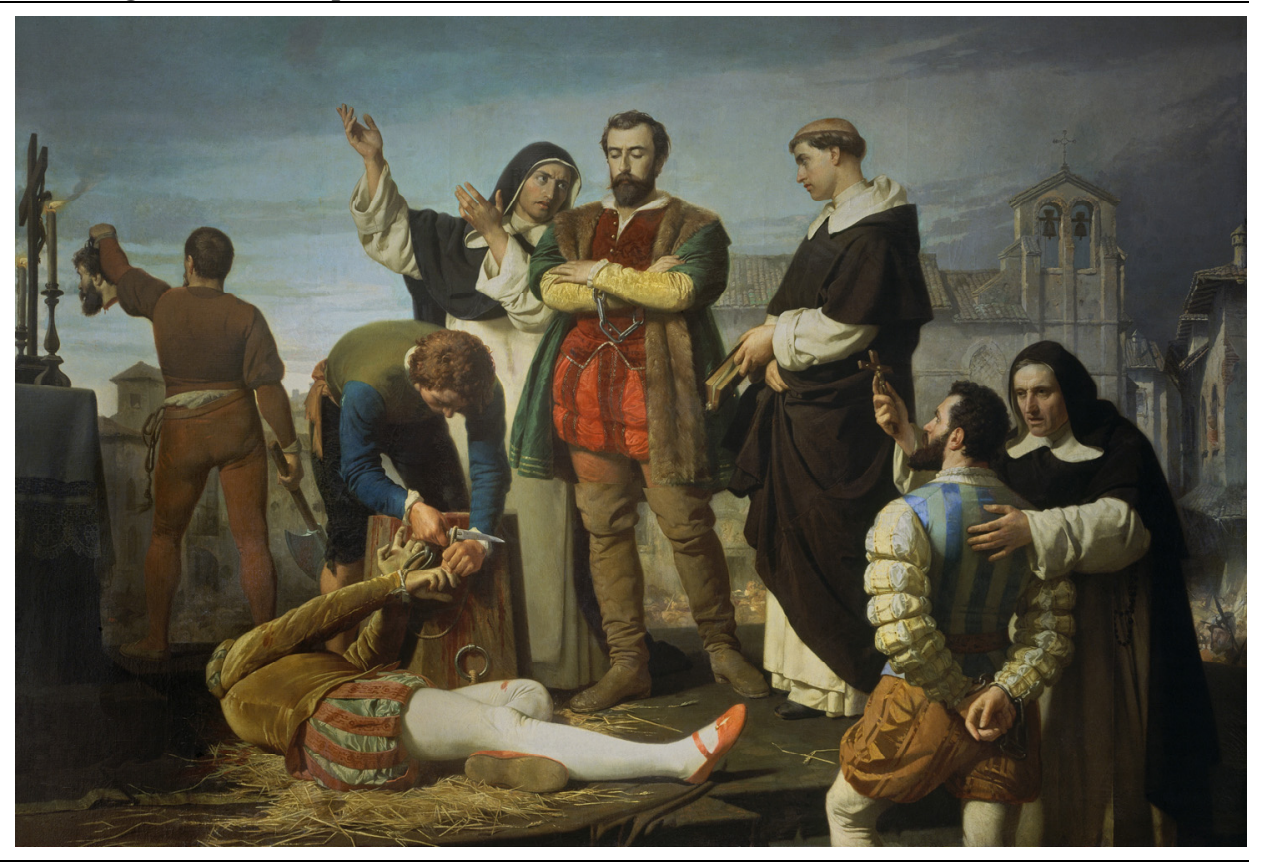

Otra característica definitoria de aquella sociedad era el papel fundamental otorgado a las relaciones de patronazgo y clientelismo. Las relaciones sociales no eran nada individualistas. La sociedad no era un conjunto desagregado de individuos. Todo el mundo pertenecía a alguna clientela, de lo contrario se corría el riesgo caer en la exclusión. Las clientelas se configuraban en un sentido vertical que conllevaba un intercambio desigual y jerárquico de lealtades, prestaciones y servicios. Entorno a las familias más poderosas de cada localidad se articulaba un dinámico clientelismo que tenía en cuenta el poder económico, el prestigio, los cargos y las relaciones privilegiadas del patrón.

La dominación de los poderosos no se imponía de ordinario mediante la coacción y la violencia, sino mediante consenso. Existían unas relaciones de dependencia en las que los de abajo necesitaban a los de arriba para subsistir, no sólo en sus apuros materiales más inmediatos, sino también en la recepción de 
favores, mercedes, protección y ayuda. A nadie se le oculta que tales relaciones eran completamente desiguales, pero ello no quiere decir que los poderosos estuviesen eximidos de obligaciones para con sus dependientes. El hecho de que estos compromisos no estuviesen regulados legalmente no quiere decir que no existiesen.

En el campo que nos ocupa ahora, el de la administración de justicia, las clientelas jugaron un papel muy relevante como encauzadoras de conflictos, intercesoras y mediadoras. Comúnmente la conflictividad menor se resolvía fuera de las instancias judiciales oficiales, mediante fórmulas creadas por la sociedad civil y en las que gremios, cofradías, corporaciones y clientelas representaron papeles estelares.

Durante el reinado de los Reyes Católicos se desplegaron corregidores por todos los confines de la corona de Castilla, hecho verdaderamente crucial en la historia de la administración, porque permitió a los reyes disponer de delegados regios independientes de los poderes locales. Su nombramiento directo por el soberano, al que representaba, $\mathrm{y}$, su condición obligada de forastero garantizaba una administración de justicia neutral e independiente de las habituales banderías existentes en las ciudades. Sin embargo ello no quiere decir que los corregidores no tuvieran en cuenta las circunstancias en las que tomaban sus decisiones. Era una justicia que rechazaba inclinarse a parcialidades, pero que entendía y defendía el contexto social en el que operaba. Por tanto no podía ser ecuánime, y, en la práctica sus actuaciones más duras quedaban reservadas para las personas menos integradas en las redes sociales, las menos relacionadas, las que menos valedores podían movilizar. Por el contrario, la personas bien insertadas en su comunidad encontraban con mayor facilidad la ayuda y comprensión de sus deudos y próximos, de sus colegas de gremio o corporación, etc. Conseguían intermediaciones influyentes de eclesiásticos, cofradías, etc. y lograban componer sus deslices con benignidades que escandalizarían a la gente de hoy día.

Desde la Baja Edad Media las dinastías europeas más importantes reforzaron y concentraron sus poderes frente a estamentos y corporaciones, de tal forma que en la Edad Moderna pudieron convertirse en monarquías absolutas. En el salto hacia el absolutismo operado durante el Renacimiento se ha resaltado el importante papel jugado por el ejército, la burocracia y la hacienda. Es cierto, sin un ejército poderoso, moderno y eficaz, armado con las costosas armas de fuego de la época, los Habsburgo no hubieran podido aspirar a la hegemonía europea. Sin una hacienda cada vez más recaudadora no hubieran podido afrontar los gastos inherentes a una costosa carrera de armamentos que parecía no tener fin. Sin embargo, debemos resaltar que en el orden interno, la administración de justicia 
jugó un papel fundamental en el desarrollo del absolutismo. Debemos recordar que durante los siglos XVI y XVII gobernar fue sinónimo de administrar justicia. No será sino hasta el siglo XVIII, en tiempos de la Ilustración, cuando los gobernantes asuman las tareas de fomento y bienestar como obligaciones propias de su oficio.

El rey absoluto justificaba su poder aduciendo que la fuente de todo poder era Dios, el cual quiso ejercerlo en la tierra a través de los príncipes soberanos. Esta es la razón por la que las monarquías absolutas no reconocían ningún poder superior y se negaban a responder de sus actos ante nadie que no fuera el mismo Dios, el día del juicio final. La potestad de dar leyes, negada a los señores, correspondía al mero y supremo poder. El rey era la fuente de todo derecho. La potestad de dar leyes y de juzgar era exclusivamente suya, pero podía delegarla en quien quisiera y por eso encontramos señores y ministros ejerciendo estas facultades en su nombre.

Para tener en cuenta el estatus social y jurídico del justiciable, así como la «calidad personal» de la víctima, fue necesario poner en funcionamiento una gran cantidad de jurisdicciones que tuvieran en cuenta los privilegios inherentes a cada persona. En el Antiguo Régimen existió una plurijurisdiccionalidad de una complejidad extrema, muy denostada por los liberales del siglo XIX por su falta de racionalidad, pero a la que no se le puede negar una cierta lógica. Las constantes fricciones entre la justicia real, señorial, eclesiástica e inquisitorial entorpecían, sin duda, las actuaciones judiciales, pero la corona encontró fórmulas para evitar que el sistema colapsara. Como hace años apuntó Tomás y Valiente, la jurisdicción señorial, la eclesiástica y la inquisitorial no actuaron nunca al margen del rey. En todas partes se aplicaba el mismo derecho: el derecho real. Además de que la corona disponía de mecanismos suficientes para controlar las jurisdicciones privilegiadas ${ }^{1}$.

Hasta la propia justicia real se administraba a través de numerosos órganos judiciales, no siempre bien jerarquizados. Entre los ministros delegados ordinarios del rey debemos citar: Los Alcaldes Mayores y Ordinarios, los Corregidores, los Adelantados, las Audiencias y Chancillerías, la Sala de Alcaldes de Casa y Corte, y el Consejo Real. La justicia delegada de excepción la constituían los jueces Pesquisidores y de Comisión. A las dos anteriores se añadía la especial privilegiada, es decir la encargada de juzgar casos relativos a miembros de ciertas corporaciones favorecidas: Hermandades, Ejército, Mesta, etc. Finalmente existía la jurisdicción específica para ciertas materias: El Consejo de Hacienda se

${ }^{1}$ Francisco tOMÁS Y VALIENTE. (1990). «De la administración de justicia al poder judicial». Jornadas sobre el poder judicial en el bicentenario de la Revolución Francesa. Madrid: Ministerio de Justicia, p. 15 y ss. 
encargaba de las causas relacionadas con las rentas reales y los Consulados de Comercio juzgaban en primera instancia pleitos mercantiles.

Recapitulando lo escrito hasta ahora indicaremos que durante la Edad Moderna se produjo un gran desarrollo de los sistemas penales. La aparición en Europa de poderosas monarquías de tendencia absolutista, permitió el desarrollo de robustos sistemas penales, desconocidos hasta entonces. Se crearon nuevos tribunales, se desplegaron jueces por todo el territorio, se profesionalizó la administración de justicia. El rey se convirtió en la única fuente de Derecho y toda la justicia se administraba en nombre del rey. Los siglos XVI y XVII fueron los tiempos de la ley y el pleito, hubo una judicialización de la vida pública en todos los sentidos.

Hubo una violencia interpersonal que estaba presente en todas las facetas de la vida. En casa los maridos pegaban a las mujeres y los padres a los hijos. En el trabajo, los oficiales y los maestros zurraban a los aprendices. En la escuela, los maestros golpeaban a sus discípulos. En las calles, duelos con espadas en defensa del honor y la honra. En la taberna, riñas frecuentes por motivos graves o livianos favorecidos por la ingesta excesiva de alcohol.

La violencia es un proceso, no es un acto puntual, aunque haya un momento en el que aparece. Había una violencia física, pero había otras más sutiles, más difíciles de percibir. Hubo una violencia familiar que dejó poca huella en los archivos judiciales, porque lo que reflejan las fuentes judiciales es el disciplinamiento: la violencia que necesita una regulación por parte del poder. No obstante en la documentación de los tribunales eclesiásticos, en las demandas de divorcio y separación, tenemos un verdadero filón para el estudio de la violencia doméstica.

La violencia constituyó un componente estructural en las sociedades preindustriales del Antiguo Régimen. Se reconocía el derecho a castigar «moderadamente» a los dependientes de cada quien. Los malos tratos estaban justificados por la necesidad de corregir los errores de los inferiores, a veces por la obligación de mantener la reputación social y la honorabilidad familiar.

Palos, coces, pescozones, bofetones, golpes, pellizcos, cardenales, magulladuras, puntapiés, «puñadas», «muxicones», «moxinetes», empellones, embarrones, encontrones, livores, coscorrones, arañazos, descalabraduras, desfiguraciones, azotes, rotura de la dentadura, lanzamientos por escaleras, arrojarle objetos... fueron hechos de la vida cotidiana en aquellos tiempos.

Igualmente existió una violencia colectiva. No nos referiremos a los grandes movimientos de profundo calado político y social: el movimiento comunero, las 
alteraciones de Aragón de 1590, la rebelión de los catalanes en 1640 o los motines de Esquilache de 1766. Existió una violencia dirigida por una mayoría contra sectores concretos de la sociedad, a los que se excluyó por motivos ideológicos, legales, étnicos o religiosos, como fue el caso de los gitanos, moriscos y judaizantes ${ }^{2}$. Como es lógico, la coerción social ejercida por la mayoría social contra minorías étnicas y religiosas no inquietó especialmente al poder establecido. Por el contrario, el bandolerismo pasó de considerarse un fenómeno local en los siglos XVI y XVII para percibirse en el siglo XVIII como una amenaza para la corona, que lo combatió tenazmente. Autores como Lope de Vega, Tirso de Molina, Cervantes y la literatura de cordel se hacen eco de un fenómeno muy presente en la sociedad de aquel tiempo. Durante los siglos XVI y XVII existió un bandolerismo de carácter nobiliario relacionado con las luchas de bandos y con viejas rivalidades familiares. Presentó su mayor incidencia en la corona de Aragón, pero toda la península, desde Andalucía a Galicia, pasando por Castilla, fue testigo de la amenaza bandolera.

Cataluña tuvo un bandolerismo del barroco muy singular que dio pie a un género literario próximo a la picaresca, mitificando personajes como Juan de Serrallonga, ajusticiado en 1633. En Valencia el bandolerismo más cruento actuó durante el reinado de Felipe II, cuando los moriscos se mostraban más inquietos, actuando como brazo armado de la aristocracia ${ }^{3}$.

Junto al bandolerismo de origen medieval y raíz nobiliaria existieron bandas de salteadores que robaban en los caminos, empujados por una profunda crisis económica y ayudados por la inestabilidad política que afectó en diferentes épocas a distintas partes de la península. En ellas se implicaban sectores marginales de la población: moriscos, gitanos, etc. Actuaban preferentemente en zonas de frontera, en tierras montañosas y periféricas. La proliferación excesiva de jurisdicciones representaba un serio obstáculo a la represión eficaz del bandolerismo. No existía una fuerza regular capaz de combatir eficazmente las bandas organizadas. La población en caso de alarma general respondía al llamamiento de las autoridades y organizaba su autodefensa.

2 Rocío SÁNCHEZ e Isabel TESTÓN. (2002). «La violencia como factor de expulsión en la Edad Moderna». En José Ignacio ForTeA, Juan Eloy Gelabert, y Tomás Antonio MANTECón (eds.). Furor et rabies: violencia, conflicto y marginación en la Edad Moderna. Santander: Universidad de Cantabria, p. 255-284.

${ }^{3}$ Vicente Graullera SANZ (2002). «Los marginados en la Corona de Aragón». En José Ignacio Fortea, Juan Eloy Gelabert, y Tomás Antonio MANTECón, (eds.). Furor et rabies: violencia, conflicto y marginación en la Edad Moderna. Santander, Universidad de Cantabria, p. 285-312. 
En un clima de violencia colectiva e interpersonal y con un arsenal de armas considerable en poder de particulares, no es de extrañar que ocurrieran «accidentes» mortales. Nadie salía a la calle desarmado. La utilización de espadas, puñales y escopetas era inevitable en cualquier incidente.

Sin embargo, a pesar de lo expuesto anteriormente debemos reconocer que en comparación con otros países europeos no existió una conflictividad mayor que en otras partes, sino todo lo contrario. En España no existieron los enconos religiosos de Francia o Inglaterra. Tampoco hubo aglomeraciones urbanas tan grandes como Londres (600.000 personas a finales del siglo XVII). Madrid era una villa menor y también mejor controlada. Además, pese a las corruptelas con las que se desenvolvía el sistema judicial, la mayoría de los súbditos confiaban en unos jueces que no habían llegado al cargo mediante sistemas venales.

Las ciudades más convulsivas durante la crisis económica del siglo XVII fueron las ciudades andaluzas: Granada, Sevilla, etc. En ellas se desencadenaron motines ocasionados por la miseria, protagonizados por consumidores desheredados, cuyos recursos no alcanzaban para llevarse a la boca una hogaza de pan. Podemos tipificarlos como de carácter urbano y de breve duración, se concentraron en los años 1648-1652. Fueron protestas contra la carestía del pan en las que jugaron su papel los especuladores y las devaluaciones monetarias con las que la corona pretendía salvar la situación de una Hacienda crónicamente deficitaria ${ }^{4}$.

Junto a la violencia física existió una violencia verbal cotidiana que actuó muchas veces como su preludio y desencadenante. En una época en la que la honra valía más que la vida, en la que la limpieza de sangre y la ortodoxia religiosa eran valores sociales primordiales, en la que la honestidad de las mujeres afectaba al honor de las familias, no se podían permitir vocablos tan injuriosos como cornudo, traidor, hereje, judío, marrano, puta o alcahueta. Pero la realidad es que en situaciones de enojo se proferían y quienes se sentían afrentados en su honor parecían obligados a defender su honra con los medios que tuvieran más a mano. Podían recurrir a los tribunales para defenderse de insultos, amenazas y calumnias, pero la mayoría de la gente entendía que la reputación y la fama salían poco favorecidas sometiéndose a tediosos sistemas de investigación judicial fundamentados sobre la base de probanzas en las que todo se ponía en tela de juicio.

4 Juan Eloy Gelabert GonZÁlez. (2002). «Tiempos de Borrasca: notas sobre la violencia política en la Castilla del siglo XVII». En José Ignacio ForTEA, Juan Eloy GelaBERT, y Tomás Antonio MANTECón, (eds.). Furor et rabies: violencia, conflicto y marginación en la Edad Moderna, Santander: Universidad de Cantabria, p. 219-238. 
La violencia existía en la sociedad y el poder político no era ajeno a ella. Al tiempo que combatía los excesos violentos de los particulares, actuaba con brutalidad sobre los cuerpos de los justiciables, imponiendo una gradación en las penas corporales que iba desde los azotes a la pena de muerte ejecutada en público y con todos los elementos de teatralidad posibles.

\section{DELITO, PECADO, JUSTICIA Y PERDÓN}

En la legislación del Antiguo Régimen no se manifiesta una preocupación por conceptualizar la noción de delito. La mayoría de las leyes penales del Antiguo Régimen eran puramente descriptivas, normalmente se limitaban a enumerar hechos que se consideraban delictivos. Desde luego, no todas las acciones reprimidas por las leyes eran delitos. Algunas de ellas eran, por ejemplo, transgresiones de mandatos reales. Es decir que de facto se distinguía entre actos «malos per se» y otros que simplemente se hacían acreedores de sanción penal porque estaban prohibidos por las leyes. La ley penal, propiamente dicha recibía entre los teólogos el nombre de mixta, porque obligaba en conciencia y en derecho.

En consonancia con la mentalidad teologista imperante en la época, la gravedad de los delitos derivaba en buena medida de su dimensión en tanto que pecados. En el Antiguo Régimen lo pecaminoso y lo delictivo se hallaban bastante próximos. Pero no eran exactamente lo mismo. Delito y pecado eran conceptos diferenciados. Trono y altar perseguían objetivos idénticos: la defensa de una sociedad en la que la idea de lo bueno y lo malo se ajustaran a los principios morales establecidos en el catolicismo de aquellos tiempos. Coincidimos con Pablo Pérez García y con Ángel Alloza, reconocemos la influencia teológica en la ley penal, aceptamos que el derecho a castigar del príncipe absoluto fue de origen divino, está probado que tras el Concilio de Trento aumentó el número de delitos de naturaleza sexual perseguidos por los tribunales reales y por los tribunales eclesiásticos, pero hubo asuntos en los que monarquía e iglesia no coincidieron plenamente o incluso colisionaron $^{5}$. A este respecto puede tenerse en cuenta lo que ocurría con la prostitución: La iglesia la condenó sin paliativos, mientras los poderes civiles toleraban que se ejerciera en el marco de ciertas normas.

5 Ángel Alloza. (2000). La vara quebrada de la justicia: un estudio histórico sobre la delincuencia madrileña entre los siglos XVI y XVII, Madrid: Catarata, pp. 188 y ss. También Pablo PÉrez GARCíA. (2002). «La criminalización de la sexualidad en la España Moderna». En José Ignacio Fortea, Juan Eloy Gelabert, y Tomás Antonio MANTeCón (eds.). Furor et rabies: violencia, conflicto y marginación en la Edad Moderna. Santander: Universidad de Cantabria, p. 355-402. 
La idea de la justicia y de la reconciliación son dos caras de las misma moneda en la religión cristiana. La clemencia es un factor fundamental para el cristiano. En Cristo hay un equilibrio perfecto entre justicia y misericordia. En el Antiguo Régimen las personas eran sujeto de derecho en tanto que eran almas. En la justicia cristiana no se procesa al reo sino el pecado. La confesión es fundamental en la reconciliación y el castigo purga el delito. Por medio de una justicia restauradora las víctimas y los verdugos edifican la justicia sobre nuevas bases.

Ilustración 2. Cristo del Perdón. Iglesia de Santa María. Medina Sidonia

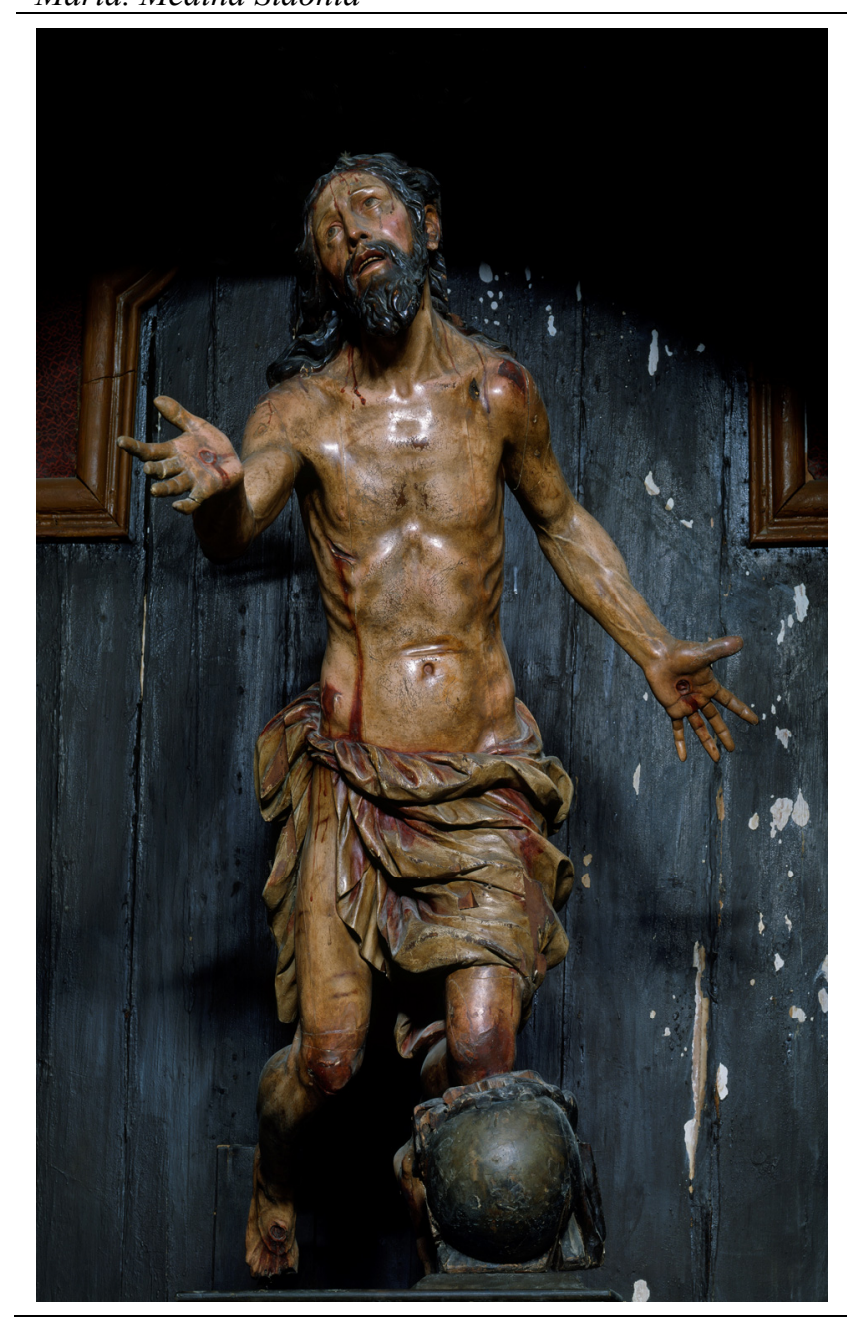


El cristiano tiene la obligación de perdonar y el rey tiene el deber de administrar justicia reparando el daño causado a la víctima por el delito. Obtenido el perdón de la parte ofendida, se podía aspirar al indulto regio. El rey haciendo uso de su potestad soberana de gracia podía indultar condenados convictos y confesos o sospechosos de delitos que se hallasen en no importa qué fase del procedimiento penal.

El indulto fue el contrapeso a un sistema judicial implacable en el que los jueces buscaban afanosamente la condena del acusado y en el que se tendía a dictar sentencias ejemplificantes sin atender a eximentes ni atenuantes.

\section{EJEMPLARIDAD, PATERNALISMO Y UTILITARISMO EN EL SISTEMA PENAL}

Con la imposición de penas, la Corona se proponía castigar al delincuente para absolver su culpa e intimidar a los súbditos con el rigor de las sanciones. El soberano sacaba importantes rendimientos en dinero y en servicios con la ejecución de las sanciones e indemnizaba a la parte perjudicada por el delito en la medida de lo posible. Todo el sistema penal era sufragado con el producto de las condenas pecuniarias e incluso la Corona podía obtener dinero líquido con la explotación del sistema de administración de justicia. La monarquía absoluta se apoyó en el ejército y la marina para proyectarse hacia el exterior y para defender sus aspiraciones hegemonistas en Europa. De ahí que una buena parte del trabajo de los penados se organizase en torno a fines militares. Aunque la pena de galeras empezó a imponerse en Cataluña desde principios del siglo XV, fue en el reinado de Carlos $\mathrm{V}$ cuando la misma se reguló y alcanzó su apogeo. A partir de esos momentos se convertiría en la pena reina del sistema penal, la más frecuente y la que revestía mayor interés para la corona, pues sin ella no podía moverse la poderosa marina del Mediterráneo, la que obtuvo éxitos tan impresionantes como la victoria contra los turcos en la batalla de Lepanto de 1571. La utilización de trabajos forzados fue habitual en los presidios, en los arsenales, en las minas, y, más tarde, en el siglo XVIII, la explotación de convictos en las obras públicas.

A lo largo de la Edad Moderna europea se observa un distanciamiento de la aparatosidad de los castigos medievales, en los que la pena de muerte se aplicaba acompañada de un sádico catálogo de suplicios perfectamente inútiles. Las minas de Almadén no fueron el destino más masivo para los trabajos forzados, pero fue, sin duda uno de los más penosos. Esta mina de mercurio fue la más importante del mundo y a partir de que que a mediados del siglo XVI se implantó el procedimiento de la amalgama para extraer la plata de las minas americanas del cerro de Potosí, se convirtió en un elemento estratégico para la corona. Los Fugger 
disfrutaron del negocio de su explotación como premio al apoyo que prestaron a Carlos V en la elección imperial. A partir de 1599 y hasta 1799 hubo forzados en Almadén. Se calcula que por allí pasaron del orden de 2.000 forzados ${ }^{6}$.

Tanto en los tiempos en los que la mina funcionó a través de un sistema de gestión privada como cuando lo hizo por explotación directa de la Real Hacienda, las calamidades de los forzados fueron las mismas. El cinabrio tenía que ser calentado por encima de los $200^{\circ}$ grados y los vapores de mercurio producían el azogamiento de los trabajadores, lo que provocaba un deterioro general del sistema nervioso. El 55\% de ellos moría antes de cumplir su condena.

Ejemplaridad, paternalismo y utilitarismo fueron las tres características esenciales del sistema penal. Los objetivos penitenciarios de aquel tiempo pueden resumirse muy bien con la clausula de las sentencias: «para que al reo sirva de castigo y a los demás de ejemplo». La vertiente ejemplificadora era esencial y de ahí que la ejecución de las penas se hiciera con la mayor publicidad. La exposición a la humillación pública, moral y física, era una parte del castigo. La sangre del reo azotado o ajusticiado en el cadalso se convertía en un elemento intimidatorio para los cientos de espectadores que asistían atemorizados y acobardados a la implacable actuación del verdugo.

Es cierto que en muchas ciudades se pasaban varios años sin que se ejecutara ninguna sentencia de muerte. Pero ello no quiere decir que el sistema penal del Antiguo Régimen fuera blando. Bastaba una simple sospecha para que alguien fuera detenido sin garantías, se le sometiera a un proceso caro, se le hicieran pasar mil sufrimientos en el potro de tortura, y se le encarcelara por tiempo indefinido cargándole los gastos de su manutención. Los jueces tenían en su mano un potencial represivo enorme que sabían administrar sabiamente. Estamos con Tomás y Valiente cuando manifestó que el desarrollo de la monarquía absoluta supuso en la corona de Castilla una mayor centralización del poder y un endurecimiento del derecho penal ${ }^{7}$. En la corona de Aragón hubo un mayor equilibrio entre el rey y el reino, lo que permitió la pervivencia durante toda la época de los Habsburgo de una penalidad más suave.

En todo caso lo que queremos subrayar es que bastaba con que se pudiese administrar la justicia con mano muy dura, para que surtiera efectos intimidatorios

${ }^{6}$ Julián Prior CABANILlas. (2006). La pena de minas: Los forzados de Almadén, 1646-1699. Ciudad Real: Lozano Comunicación Gráfica, p. 39 y ss.

${ }^{7}$ Francisco TOMÁs y VALIENTE. (2000). La tortura judicial en España. Barcelona: Crítica, pp. 215 y ss. 
evidentes. Los valentones, como se les llamaba en la época. Esto es, los hampones, sabían las dificultades que tenían los oficiales de justicia para perseguir los delitos con los limitados medios que tenían a su alcance, pero su osadía, por grande que fuera, nunca pudo poner en jaque la estabilidad social porque la justicia compensaba su ineficiencia con un rigor terrorífico. Bastaba con haber asistido a alguna ejecución para que la imagen del ahorcado o del degollado quedase grabada para siempre en el espectador. Sabemos que los rollos representaban jurisdicción y legalidad, pero también causaban sobresalto a las personas que pasaban junto a ellos ${ }^{8}$.

\section{TIPOLOGÍA DE LOS DELITOS}

En función de los efectos que se querían proteger podemos agrupar los delitos en las siguientes categorías: Delitos contra Dios y la Religión, Delitos contra los Derechos e Intereses de la Corona y contra la Administración de Justicia, Delitos contra la Vida e Integridad de las Personas, Delitos contra el Patrimonio, Delitos de Naturaleza Sexual y Delitos contra el Orden Público. Según los tribunales y las zonas variará la proporción de cada uno de ellos. En la jurisdicción eclesiástica predominaban los que tenían relación con la moral de las costumbres y en la jurisdicción real los atentados contra la propiedad.

En todo caso, podemos afirmar que al sistema judicial de aquel tiempo le preocupaban especialmente los delitos contra el patrimonio y contra la integridad física de las personas. Más de la mitad de sus actuaciones estaban relacionadas con ellos. La sociedad confiaba en el sistema judicial para perseguirlos y la corona se prestigiaba y ganaba apoyos cuando administraba una buena justicia. La imagen del rey juez, capaz de restituir en sus derechos tanto a los poderosos como a los humildes, era la más apreciada para ganar buena reputación.

No hubo en aquella época una delincuencia específica para cada edad. Los jóvenes cometían delitos similares a los perpetrados por personas adultas. Siempre las infracciones contra la propiedad ajena destacaban sobre todas las demás y los atentados contra las vida y la integridad de las personas le seguían de cerca. Ello no quiere decir que a los jueces no les importara la protección de bienes inmateriales. En las leyes aparecen tipificados los delitos de blasfemia o los juramentos en vano .

${ }^{8}$ Antonino GonzÁlez Blanco (2006). «Horcas, rollos y picotas en la mentalidad del Barroco». En Concepción DE LA PeÑa Velasco (edit.). En torno al Barroco miradas múltiples. Murcia: Universidad de Murcia, pp. 55 y ss.

${ }^{9}$ Nueva Recopilación 1, 1, 10. 
Significativamente la Nueva Recopilación abre sus páginas instando a los súbditos a creer en los misterios defendidos por la Iglesia Católica. Es verdad que los casos de esta naturaleza perseguidos en la jurisdicción civil no fueron muchos, pero debe tenerse en cuenta que para la defensa de la fe se creó una jurisdicción especial: la Inquisición, la cual tenía una naturaleza mixta, real y eclesiástica al mismo tiempo. Actuaba con procedimientos muy expeditivos y condenó a muchos miles de personas, a veces por heterodoxias muy leves.

Los delitos de naturaleza sexual (estupros, violaciones, raptos, amancebamientos, adulterios, tratos ilícitos, «inquietar casadas», «solicitar mujeres», «perseguir doncellas», etc.) eran reprimidos por la justicia real, por la justicia eclesiástica y por la Inquisición. Llamamos la atención sobre el hecho de que en este campo el bien protegido no suele ser el interés de la mujer, sino la honra del padre o del marido.

Como es lógico, en una sociedad en la que la honra se consideraba más importante que la vida, la defensa del honor estaba blindada por el sistema legal. Entre la documentación judicial podemos encontrar numerosos pleitos litigados para resolver diferencias tan intrascendentes a nuestro ojos como el lugar correspondiente a cierta persona en una ceremonia religiosa o qué carruaje debía ceder el paso al otro en una calle estrecha.

Se imponían fuertes sanciones económicas a quien llamase leproso, sodomita, cornudo, traidor o hereje a un semejante. Esas palabras y otras análogas como judío, negro, gitano, ladrón, pícaro o borracho están en el inicio de pendencias, a veces con final trágico. Contra la mujer el insulto mayor era llamarla puta.

La justicia no podía proceder de oficio en estos casos, sino sólo a petición de parte, lo que sin duda redujo el número de los que se dirimieron ante los jueces. Someter la honra propia al sistema probatorio imperante en el sistema judicial de la época, era correr riesgos, que era preferible evitar. La sociedad supo encontrar cauces extrajudiciales paralelos para componer al agraviado y al ofensor a través de la intermediación de terceros. Sin descartar que eventualmente la víctima se defendiese del ultraje con el acero de su propia espada, a veces con el fatal desenlace de la muerte de uno de los contendientes.

Es significativo de la poca movilidad existente en la época que, salvo en los casos de asaltos en los caminos, la mayoría de las personas implicadas en los delitos vivían en la misma población o en localidades vecinas.

Las mujeres registraron estadísticas de criminalidad mucho más bajas que los hombres -cuatro o cinco veces menos-. Además, su implicación en los delitos fue 
diferente. La mayor parte de las veces aparece como cómplice o relacionada con delitos de naturaleza sexual.

\section{EL CATÁlOGO PUNITIVO}

\subsection{El sistema carcelario}

En un sistema punitivo tan utilitarista como el de los Habsburgo el encarcelamiento se consideraba un gasto absurdo. Las prisiones no estaban concebidas como lugares de castigo, sino como espacios en los que custodiar a los presuntos culpables hasta que se celebrase el juicio y se dictase la correspondiente sentencia ${ }^{10}$. La pena de prisión se impuso en un número limitado de casos. En general servía para sancionar delitos leves y duraba un corto período de tiempo. Es decir, la cárcel como pena, era un elemento accesorio en el sistema punitivo del Antiguo Régimen. La realidad es que las cárceles acogían a los detenidos en espera de juicio para asegurar que estaban a disposición de la justicia en tanto se instruían procesos contra ellos.

No existían normas reguladoras de su régimen interno, de tal manera que jueces y carceleros actuaban de forma arbitraria. La manutención de los reclusos corría por cuenta de ellos mismos. Cada juzgado poseía su propia cárcel y como existía una enorme cantidad de jurisdicciones, el número de locales utilizados con fines carcelarios fue innumerable. En los lugares pequeños no había cárceles permanentes y con frecuencia se utilizaban domicilios particulares de oficiales de justicia.

Durante la Edad Moderna no existió un criterio de ordenación espacial en la arquitectura carcelaria. Dependencias administrativas, judiciales y penitenciarias se mezclaban en un estado de confusión considerable. En época de los Habsburgo descollaron dos edificios carcelarios: la cárcel de Sevilla -construida en 1418 pero reformada en 1569- y la cárcel de corte -hoy Ministerio de Asuntos Exteriores-, inaugurada en 1634 .

Es cierto que a lo largo de la Edad Moderna fue cambiando muy lentamente la idea de la prisión. Volviéndose un poco más punitiva, pero en general fue una pena mínima para delitos de escasa entidad y fundamentalmente siguió siendo un depósito cautelar al servicio del procedimiento penal.

La corrupción de los carceleros posibilitaba que detenidos por delitos muy graves tuviesen una dulce prisión si se avenían a pagar bastante dinero al alcaide.

${ }^{10}$ Partida IV, 3, 4; Partida VII, 29, 1. 
Las corruptelas estaban extendidas por doquier, pero, no obstante, las prisiones fueron espacios de sufrimiento ${ }^{11}$. Ser encarcelado en el Antiguo Régimen era una desgracia muy grande. Se utilizaban edificios viejos, deteriorados y mal acondicionados. Los carceleros extorsionaban continuamente a los presos . Existía hacinamiento y malas condiciones higiénicas. El riesgo de contraer enfermedades era muy alto.

Ilustración 3. Fachada de la cárcel de Corte. Sede actual del Ministerio de Asuntos Exteriores. Diseñada por el arquitecto Juan Gómez de Mora. Inaugurada en 1634

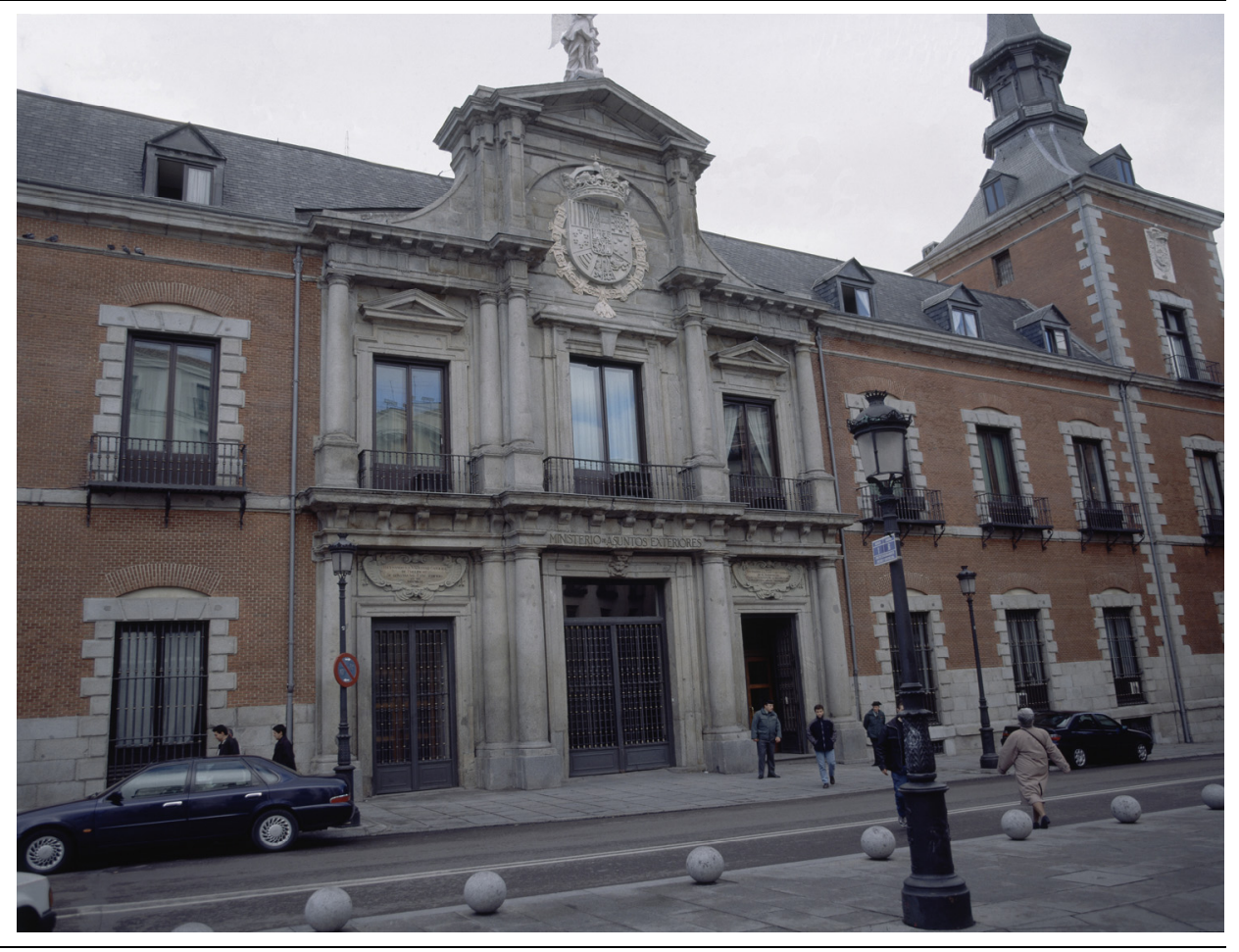

\subsection{Las penas pecuniarias}

Fueron un ejemplo más del utilitarismo en la administración de justicia. Sirvieron, entre otras cosas, para que el sistema judicial se autofinanciara. Gracias a ellas se pagaban los sueldos de los ministros, se recompensaban confidentes, se

11 Bernardino De SAndoval. (1564). Tractado del cuidado que se ha de tener de los presos pobres. Toledo: Miguel Ferrer, p. 2. 
indemnizaba a la parte perjudicada, se realizaban acciones piadosas, y, cuando se podía, incluso se ejecutaban obras públicas. Sin duda fueron un elemento perverso del sistema judicial: los jueces tenían interés personal en condenar a los reos para cobrar sus salarios ${ }^{12}$.

«El procurador del rey», «el procurador fiscal» era en la Baja Edad Media un cargo que reflejaba muy bien la nueva dimensión política de una monarquía que no dejaba de ganar terreno frente a otros poderes. Su dependencia con sus orígenes patrimoniales son evidentes, pues en un principio sólo actuaba en delitos castigados con penas pecuniarias. Su función fiscal se confundía con la de promotor de la justicia. En época de los Reyes Católicos se precisó la actuación institucional del procurador fiscal como figura directamente vinculada al servicio del rey en su triple esfera patrimonial, jurídica y política. Así se dispuso en el ordenamiento de las Cortes de Toledo de $1480^{13}$. Estos son los orígenes de nuestro actual Ministerio Público, un cargo que en tiempos de la monarquía absoluta estuvo íntimamente ligado a los intereses de la corona, tanto a los políticos como a los económicos.

En muchas sentencias se establecía una distribución de las penas pecuniarias para penas de cámara y gastos de justicia. Sin embargo esta distinción era a menudo puramente teórica pues en la práctica se sufragaban gastos de justicia con penas de cámara y viceversa. En relación con los ingresos globales de la monarquía, el dinero líquido ingresado por la administración de justicia era muy poco, pero debe tenerse en cuenta que era una cantidad suficiente para pagar a todos los oficiales del sistema judicial y que el mantenimiento de este aparato tenía una importancia capital para el gobierno de los reinos.

La confiscación total de bienes se contemplaba en la legislación pero era francamente excepcional. Se impuso en pocas sentencias y menos veces aún llegó a ejecutarse. A éste respecto téngase en cuenta que en la época se tendía a considerar la propiedad como patrimonio familiar y no como fortuna individual. La propiedad vinculada a mayorazgos era inembargable por ley y en los demás casos los jueces tenían cuidado para no dejar en la ruina a toda la familia.

12 María Paz Alonso Romero. (1985) «Aproximación al estudio de las penas pecuniarias en Castilla (siglos XIII a XVIII)». Anuario de Historia del Derecho Español, 55, p. 93.

13 Santos M. Corona GonzÁLez. (1992). Ilustración y Derecho: Los fiscales del Consejo de Castilla en el siglo XVIII, Madrid: Ministerio para las Administraciones Públicas, p. 39 y ss. 


\subsection{Las penas corporales}

Una de las funciones de la justicia penal es prevenir futuros delitos. En aquel tiempo se entendía que la mejor manera de evitarlos era atemorizando a los posibles delincuentes. De ahí que la publicidad de las penas se buscara abiertamente ${ }^{14}$. En Castilla, a diferencia de Francia y otros países, la pena de vergüenza pública iba indefectiblemente unida a la de azotes. La flagelación del reo se hacía en la vía pública y con el refuerzo publicitario del pregón anunciador del motivo del ajusticiamiento. La pena corporal más ordinaria eran los azotes administrados en cantidad proporcional a la gravedad del delito. Su número más habitual oscilaba entre los 100 y los 400 golpes. Este tipo de penas sólo se podían aplicar a los pecheros. Los hidalgos tenían el privilegio de estar excluidos de ellas porque se consideraban infamantes. Generalmente en los casos que a un plebeyo se le imponían azotes y vergüenza pública a los hidalgos se les imponía el destierro por un cierto número de años.

En algunos momentos de la Edad Media se aplicó en Castilla la mutilación de miembros, pero en los tiempos modernos fue francamente infrecuente. De hecho, si alguna vez se aplicó fue como pena accesoria, previa a la pena de muerte ${ }^{15}$. En la Edad Media se aplicaron penas tan crueles como sacar los ojos, marcar la cara, cortar las narices... Pero las Partidas del rey Alfonso X el Sabio las prohibieron ${ }^{16}$.

No se podía marcar la cara pero se podían hacer señales en otras partes del cuerpo, si bien es verdad que ello se hizo con poca profusión. Su uso quedó reducido al sellado de ladrones y vagabundos para distinguirlos en caso de reincidencia y castigarlos más severamente.

Por último, debemos añadir que algunas veces se agravaba sádicamente la ejecución de la pena capital con el atenazamiento del reo. Consistía esta pena en sacar pedazos de carne del pecho con tenazas de hierro al rojo vivo. Estos sufrimientos horribles se reservaban para los autores de delitos atrocísimos.

\subsection{Destierro}

En el derecho contemporáneo la pena de destierro tiene un encaje difícil, fundamentalmente porque los países vecinos no tienen por qué aceptar al

14 Ismael ALMAZÁn FERNÁNDEZ. (1992). «Penas corporales y disciplina social en la justicia catalana de los siglos XVI y XVII». Pedralbes, 12, pp. 127-148.

${ }^{15}$ Gregorio Marañón (2005). «La vida en galeras en tiempos de Felipe II». Ars Medica. Revista de Humanidades, 4, pp. 217-237.

${ }^{16}$ Partida VII, 31, 6. 
desterrado. Esta pena suponía la exclusión de una persona de la comunidad de la que formaba parte. De alguna forma quien cometía un delito grave rompía el pacto de lealtad y obediencia que debía a su rey. El delincuente atacaba con sus actos las reglas vigentes y por tanto la autoridad legítima le expulsaba. Podía echarle de un manera temporal o definitiva. Las faltas más graves se castigaban con un destierro más lejano y más largo.

En la Edad Media había sido un castigo esencialmente nobiliario que fue extendiéndose y más tarde se aplicó también a personas de las clases medias. Como no era pena infamante se aplicaba a personas de reputación a las que no se quería menoscabar la honra personal o familiar. Podríamos decir que el destierro era para estos grupos sociales encumbrados el equivalente de las galeras para la gente común. En las Partidas se establece el destierro en una isla como el destierro más riguroso ${ }^{17}$. Con la colonización americana se empezaron a conmutar penas de galeras, destierros en islas y expulsión de los dominios de la corona por deportación a los territorios americanos durante un número -en teoría- limitado de años.

En la práctica judicial se imponía el destierro a los poderosos y las galeras a los humildes para delitos semejantes, aunque desde luego los sufrimientos no eran parecidos. Es innegable que el destierro causaba perjuicio. Al desterrado se le apartaba de su entorno natural y en consecuencia no podía recibir los favores y servicios de la red clientelar en la que vivía habitualmente. Igualmente le apartaba de la merced real, cuestión de capital importancia para la nobleza de la época. $\mathrm{Si}$ embargo no conllevaba las enormes fatigas de las galeras. Por otra parte, en una sociedad en la que las clases dominantes eran rentistas, su imposición a este tipo de personas no causaba su ruina económica.

Burlar la condena de destierro era relativamente fácil porque no se podía controlar a los desterrados. Éstos se limitaban a obtener constancia escrita de su paso por la frontera en una determinada fecha, y, después, pasado un tiempo, se podía regresar clandestinamente a las proximidades de su domicilio. Los archivos judiciales están llenos de casos de reos a los que se les impuso una segunda condena por quebrantamiento de destierro. En la legislación estaba previsto doblarles la pena, pero era más práctico imponerles una fuerte multa y así se aseguraban de que no volvería a quebrantarlo.

${ }^{17}$ Partida VII, 31, 4. 


\subsection{Servicios Militares}

La pena de galeras era sin lugar a dudas un servicio militar imprescindible para la acción exterior de la monarquía en el Mediterráneo, pero ahora nos referiremos a otros servicios castrenses que también se impusieron en la Edad Moderna.

Los ejércitos de los Habsburgo se abastecían fundamentalmente de mercenarios, pero con carácter complementario ingresaban en él algunos condenados por la justicia. Altos personajes de la nobleza tuvieron que cumplir importantes servicios militares por condena.

Los presidios del norte de África eran fundamentales para mantener la posición militar en la «otra orilla» y controlar los movimientos de las flotas musulmanas. Eran al mismo tiempo elementos de defensa, de avanzadilla y de dominación de un territorio concreto. En esas circunstancias la vida de sus pobladores era tremendamente dura y en su interior no solo hacían falta soldados, también profesionales de oficios concretos: albañiles, carpinteros, cerrajeros, alpargateros, sastres, barberos... Pero no se encontraban personas voluntarias para acudir a estos destinos. Por tanto fue preciso cubrir estas necesidades con penados. De la condena en ellos se ha adoptado en la lengua castellana el vocablo preso como sinónimo de encarcelado.

Acorde con la gravedad de la pena se castigaban con ella delitos muy importantes. Se la consideraba próxima a la pena de muerte y semejante a la de galeras. En realidad ir a parar a una nave o a un presidio dependía de las circunstancias del momento y de las necesidades de la monarquía, aunque también influía la logística, la capacidad de transporte hacia un lugar o hacia otro.

En el siglo XVIII, la mayor parte de las condenas a trabajos forzados castrenses se efectuaron en los arsenales de la marina, donde podían ser destinados a las bombas de achique, pontones, tala de árboles, buceo, almacenes, fabricación de pólvora, etc.

\subsection{Trabajos forzados}

La corona cubría con mano de obra forzada actividades productivas penosas y peligrosas para las que no se encontraban trabajadores libres. Dentro de éstas destacaban por su importancia las extracciones mineras. Ya en tiempos de los romanos se contemplaba la pena de trabajos forzados en la minas del Estado e igualmente las Partidas del Rey Sabio la recogieron en el catálogo de castigos penales. Sin embargo a comienzos de la Edad Moderna este castigo había perdido mucha importancia. 
Antes de 1555 el azogue, que es como se llamaba al mercurio, tenía un interés secundario, pero al introducirse ese año en América la amalgama de dicho metal con el mineral argentífero fue necesario intensificar la explotación de las minas de mercurio. El feliz descubrimiento de Bartolomé de Medina consistía en triturar el mineral con mazos o molinos de fuerza hidráulica o animal. Después se mezclaba con mercurio, sal y otros productos, según la calidad del mineral, bajo supervisión de un experto: el azoguero. Pasados de dos a cinco meses se conseguía la amalgama. Después se exprimía la mezcla para liberarla de impurezas y se obtenían las piñas de plata y mercurio. A continuación por destilación al fuego se separaba la plata del mercurio ${ }^{18}$.

Ilustración 4. Recreación del trabajo forzado en las minas (Parque Minero de Almadén)

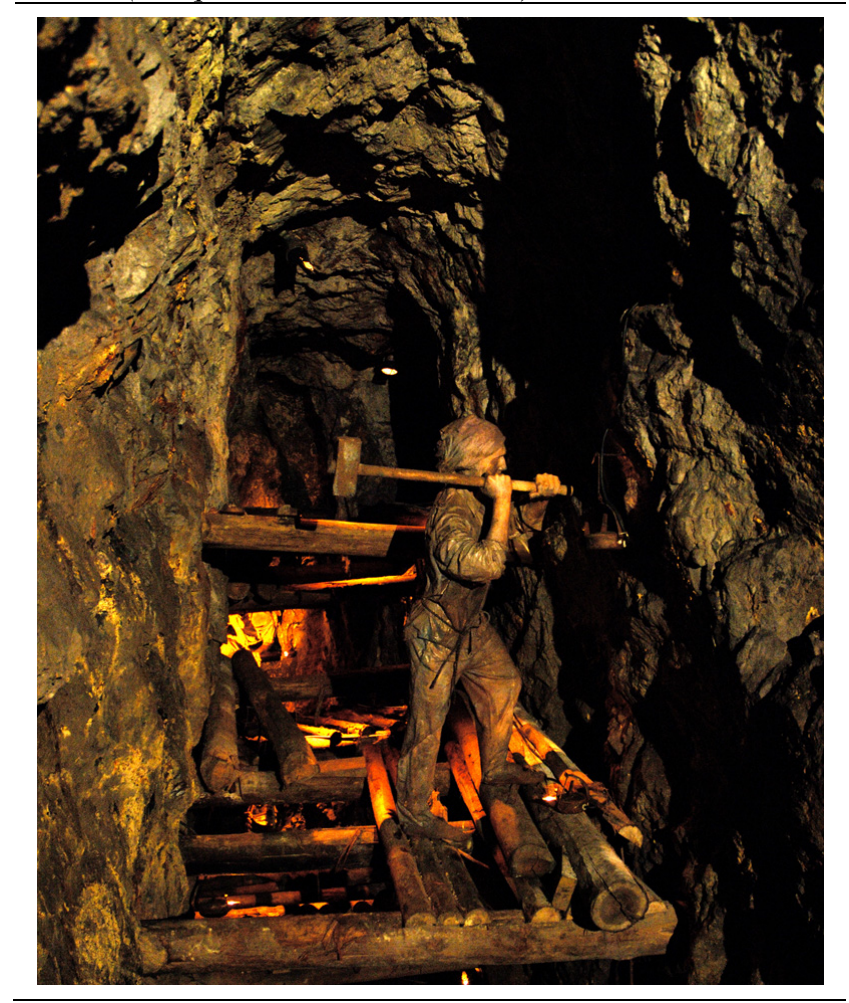

18 Demetrio RAMOS PÉREZ (coord.). (1992). Historia General de España y América. Madrid: Rialp, 1992, p 669. 
La necesidad de extraer mercurio aumentó de tal manera que en 1559 los agentes de los Fugger en el Campo de Calatrava propusieron al rey que asignasen 30 galeotes al servicio de las minas de Almadén, demanda que en un principio fue rechazada. Pero como los contingentes de mercurio no alcanzaban las cantidades pactadas en el contrato, la corona acabó cediendo a las demandas de los asentistas. En 1570 se aumentó el número de forzados a 40.

En 1590 la mina fue inspeccionada por Mateo Alemán, el autor del Guzmán de Alfarache. En su informe a la corona detalló muchas cosas relativas al trabajo de los forzados, pero en síntesis podemos resumirlas indicando que la situación de los mineros era tan desgraciada que envidiaban la suerte de los galeotes.

A mediados del siglo XVII se incendió la explotación almadenense, lo que provocó el abandono del complejo minero por los financieros de Augsburgo. Tardó en reanudarse la actividad minera y cuando se hizo, fue bajo la dirección del Consejo de Hacienda.

En 1683 había en Almadén 106 forzados, que se encargaban de la extracción del mineral y del desagüe de la mina mediante bombas manuales.

Desde siempre se había sabido que los trabajos en Almadén eran muy peligrosos para la salud. La intoxicación por los vapores de mercurio causaba enfermedades nerviosas y las altas temperaturas de lo hornos -a los que había que entrar para retirar el producto final- producían quemaduras y enfermedades dermatológicas. Sin embargo hasta 1690 no se dieron órdenes para aminorar un poco las condenas y aún así solo se rebajó un año sobre el tiempo nominal establecido en la sentencia.

En tales circunstancias no debe extrañar que en 1701 se ofreciera a unos condenados a galeras la posibilidad de cumplir sus condenas en Almadén con una rebaja de dos años y no aceptaron porque sabían que ir a trabajar en el azogue era una muerte segura ${ }^{19}$. Julián Antonio Prior Cabanillas manifiesta que la probabilidad de morir en la mina durante el período de condena era del $40 \%$, pero seguramente esta cifra se quede corta, como ya hemos indicado anteriormente ${ }^{20}$.

Por último debemos señalar que en Almadén se construyó a mediados del siglo XVI la primera cárcel destinada al cumplimiento de pena, un hecho verdaderamente insólito en la penalidad de la época, pero muy necesario para

\footnotetext{
${ }^{19}$ Archivo Histórico Nacional, Consejos, Sala de Alcaldes, libro del año 1701, fol. 194.

${ }^{20}$ Julián Prior CABANiLlas. (2006). La pena de minas: Los forzados de Almadén, 1646-1699. Ciudad Real: Lozano Comunicación Gráfica, p 103.
} 
mantener a buen recaudo a los forzados. La llamada cárcel vieja o crujía fue utilizada hasta 1756 , fecha en la que se inauguró otro edificio para el mismo fin, llamado Real Cárcel ${ }^{21}$.

\subsection{Pena de galeras}

Esta pena tuvo una evolución distinta en la Corona de Castilla que en la Corona de Aragón. En Cataluña se empezó a imponer tempranamente, esto es, a comienzos del siglo XV y es un hecho que en 1438 estaba plenamente establecida en todos los territorios de la Corona de Aragón.

En Castilla fue introducida por Fernando el Católico, siendo Carlos V quien la reguló plenamente y perfiló los delitos acreedores de la misma. En tiempos de Felipe II aumentó considerablemente el poderío de la flota de galeras en el Mediterráneo. Para obtener la fuerza motora necesaria prolongó la duración de las condenas a remo y amplió el número de delitos sancionables con ellas, tanto en la Corona de Castilla como en la Corona de Aragón. Aunque no todos los remeros eran galeotes, es preciso indicar que éstos constituían el motor fundamental de la marina de guerra mediterránea.

En un principio no se confeccionó ninguna lista de delitos sancionables con tal castigo, simplemente se autorizó la conmutación de penas corporales, destierros y otras similares por servicios de galeras. De todos modos un repaso a la legislación penal de la época pone de relieve que con el paso del tiempo un buen número de delincuentes fueron a parar a los bancos de las galeras: ladrones, blasfemos, bígamos, testigos falsos, desertores, huidos de prisión, vagabundos, obstaculizadores de la acción de la justicia, etc.

No se consideraba pena infamante y en teoría se podía imponer tanto a hidalgos como a plebeyos, pero fue raro ver hidalgos en los bancos de las galeras.

A mediados del siglo XVII los barcos de remo entran en declive y en la últimas décadas de la citada centuria fueron ganando auge las sentencias a los presidios del norte de África. Tras la paz de Aquisgrán de 1748, que puso fin a la Guerra de Sucesión Austriaca, Fernando VI suprimió las galeras. A partir de esos momentos los forzados serían enviados a las minas de Almadén, a Indias, presidios del norte de África, obras públicas y arsenales de la marina. La construcción del arsenal de Cartagena aprovechó intensivamente esta mano de obra barata hasta su terminación en 1782 .

21 Ángel M. Hernández Sobrino. (2010). Los esclavos del Rey. Ciudad Real: Fundación Almadén, p. 41 y ss. 
Ilustración 5. Condenados a galeras. Recreación en el Museo Marítimo de Barcelona

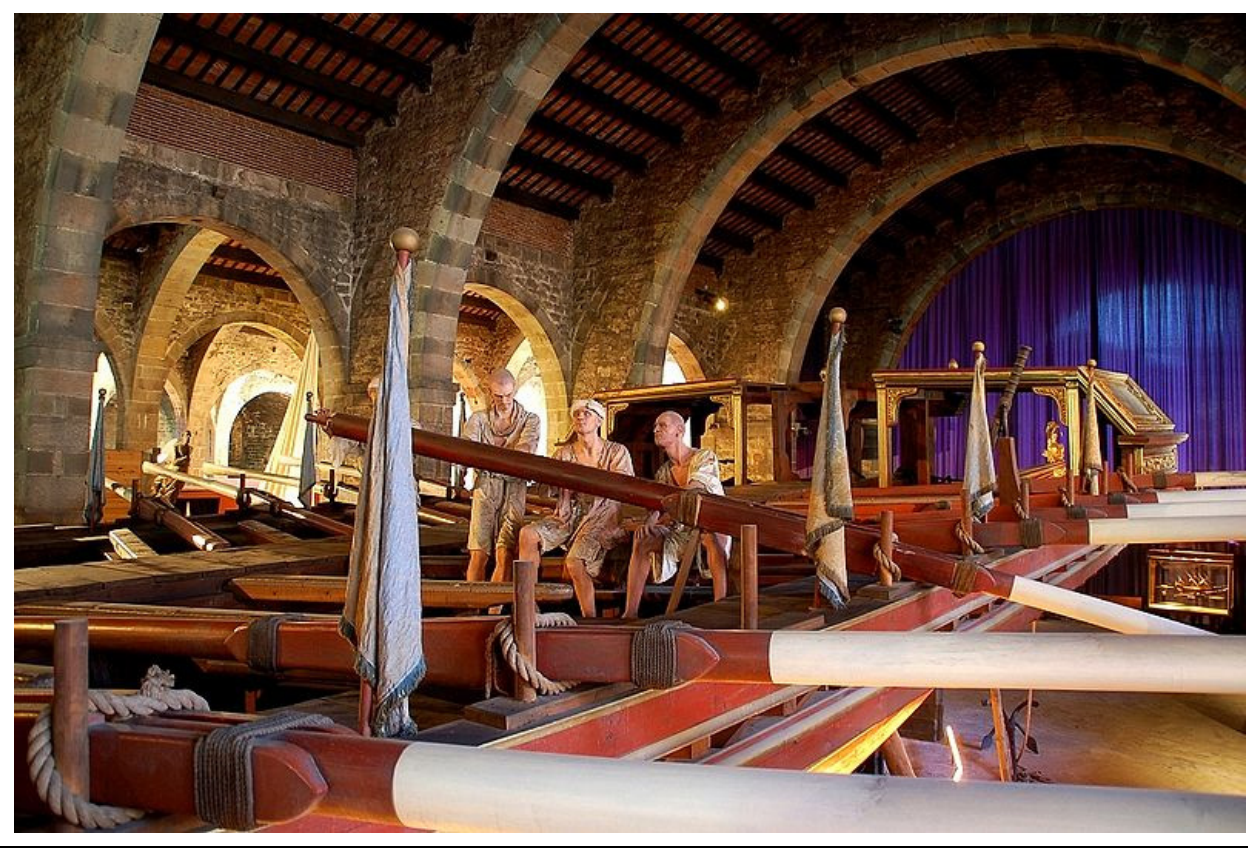

En 1784. Carlos III restableció de nuevo la flota de galeras para combatir la operaciones de corso de piratas argelinos, pero en 1804 fueron suprimidas definitivamente por Carlos IV.

El índice de mortalidad de los galeotes era alto: el 13\% a finales del siglo $\mathrm{XVI}^{22}$, lo cual obligaba a renovar la totalidad de la fuerza cada siete años. La insalubridad de las galeras era muy grande. Los galeotes hacían todas sus necesidades fisiológicas encadenados al banco. La pestilencia era horrible. La chusma, que es como se llamaba al conjunto de los remeros estaba permanentemente mojada. La galera era un barco de casco bajo. La mayor parte de ella carecía de cubierta. Por la noche se cubría con unos tendales, pero éstos no podían extenderse durante la navegación. En consecuencia las olas salpicaban el interior del barco y las espaldas de esta gente se llenaban de salitre, causándoles enfermedades de la piel.

22 Bartolomé Bennassar. (1996). El galeote de Argel. Vida y hechos de Mustafá de Six-Fours, Barcelona: Edhasa, pp. 52 y 53. 
La boga requería un esfuerzo físico considerable. Los brazos no eran los únicos miembros que se ejercitaban. El manejo del remo requería un ajetreo continuo de todo el cuerpo. Había que levantarse y sentarse continuamente, avanzar hacia adelante y hacia atrás; y así continuamente, sin parar.

La política naval determinó el número de penas de galeras impuestas por los jueces y la corona no dudó en presionar a las justicias para que éstas atendieran las necesidades militares del soberano, aunque fuera con menoscabo de la estricta administración de justicia.

\subsection{La pena capital}

Se reservaba para los delitos atroces y los causantes de mucho escándalo. La teatralización y solemnidad de su administración servían para representar la victoria de la justicia sobre los transgresores del orden.

El impacto sobre la concurrencia era tremendo y permitía ocultar la realidad de una administración de justicia con niveles de eficiencia bajos. Se imponía para castigar delitos de lesa majestad, los contrarios a la fe, homicidios, homosexualidad, bestialidad y delitos contra la propiedad.

Generalmente los delitos contra la propiedad se solían castigar con galeras pero en ciertas circunstancias se castigaban con la pena capital para sancionar los agravantes de despoblado y reincidencia. Existían diversas formas de aplicar la pena de muerte: horca, degollación, hoguera, asaetamiento, garrote, encubamiento, y con carácter excepcionalísimo la rueda.

Antonio Pérez, el secretario de Estado de Felipe II era partidario de castigar con la pena de muerte exclusivamente los homicidios, pues «el hombre muerto es un hombre perdido para el Estado». En conclusión, este estadista se pronunciaba a favor de los trabajos forzados generalizados ${ }^{23}$. Un razonamiento muy acorde con la práctica penal de su tiempo.

Algunas formas de aplicación de la pena de muerte eran específicas de cierto estamento, de un determinado delito o de un tribunal determinado. La degollación era un privilegio de los hidalgos. La horca, sin embargo, se aplicaba a los plebeyos. Se consideraba pena infamante.

${ }^{23}$ Máximas de Antonio Pérez dadas a Enrique IV de Francia. Biblioteca Nacional, ms. 11.352, fols. 67-68. 
Característico de las Hermandades fue asaetear a los criminales. Si bien, desde 1532 por disposición de Carlos V se obligó a que antes de lanzarles las flechas fueran ahorcados.

Los caballeros de las Órdenes Militares tenían el privilegio de ser ejecutados en secreto y por el procedimiento del garrote, técnica que en aquellos momentos era poco usada. Sería Fernando VII el que se encargaría de generalizar su uso a partir de 1832 tras prohibir el uso de la horca. Los parricidas y los uxoricidas eran introducidos en el interior de una cuba o de un odre, junto con una mona, un perro o una víbora y se les arrojaba al agua.

En los delitos agravados la justicia no se conformaba con matar al delincuente. Camino del cadalso algunos delincuentes podían ser atenazados en sus carnes con instrumentos candentes, o ser mutilados de alguno de sus miembros.

En muchas sentencias se mandaban exponer los cuartos del cadáver en diversos sitios de mucho paso. Con ello se multiplicaban los efectos intimidatorios y ejemplificantes de la ejecución.

Existía todo un ritual en la aplicación de la pena capital. Comunicada la sentencia por el escribano al interesado, pasaba tres días en capilla atendido por un confesor. Llegado el día señalado, si el reo deseaba vestir de luto, se le permitía. Sin embargo la Santa Hermandad les obligaba a vestir un hábito verde típico y la Inquisición los cubría con el célebre sambenito.

Desde la puerta de la cárcel se formaba un cortejo con gran gentío, al frente del cual iban los alguaciles, el escribano, el pregonero que publicaba el delito cometido y el reo montado al revés en un jumento.

Llegados al cadalso el verdugo se acercaba al paciente y le pedía perdón al oído. Después el predicador se dirigía a la concurrencia aludiendo a temas relacionados con el delito imputado al reo: «Mírate aquí en este tu espejo. No aguardes pecador a que se enoje Dios contigo y te entregue en las manos de la justicia» ${ }^{24}$.

Generalmente los reos morían confesados, comulgados y dando pruebas sinceras de arrepentimiento. A ello contribuía de forma decisiva la labor del confesor. Rara vez ocurrían incidentes. La imagen de la justicia no podía ser más triunfal. En muchas ciudades existían cofradías para consolar a los condenados: La

24 «Cartas de algunos padres de la Compañía de Jesús sobre sucesos de la Monarquía entre los años 1634 y 1648», en Memorial Histórico Español. Madrid, 1861-65. T. XVIII. p. 466 y 467. 
Santa Caridad, La Misericordia, la Vera Cruz, la Hermandad de la Sangre de Cristo...

\section{ALGUNAS REFLEXIONES FINALES:}

¿Justicia dura o justicia blanda? Ambas cosas podía ser la justicia de la época de los Habsburgo. Dependiendo de las circunstancias y de la persona del delincuente, el mismo delito podía tener una pena bien diferente; o incluso mejor, podía ser objeto de alguna composición ventajosa con la parte perjudicada, generalmente a cambio de una cierta cantidad de dinero.

Ello no quiere decir que los delitos quedasen impunes. A veces sí, por ineficiencia del sistema, pero desde los tiempos de los Reyes Católicos existió la opinión generalizada de que la justicia actuaba y podía hacerlo con gran contundencia. Otra cosa es que en paralelo con el sistema judicial existiesen mecanismos extrajudiciales para resolver conflictos, los cuales existieron en otras partes de Europa en mayor medida que en la Corona de Castilla, donde el desarrollo del absolutismo fue más temprano y más profundo. Tomás Mantecón se ha referido a este fenómeno como justicia participada por la sociedad y negociada entre las partes, tanto negociada entre las partes como sancionada por el rey a través de su consejo de la Cámara de Castilla. La resolución de los litigios penales podía derivar en una compleja combinatoria en la que intervenían principios penales vigentes, prácticas judiciales establecidas en el sistema legal, valores éticos fuertemente arraigados, costumbres convivenciales no escritas y fundamentos cristianos alusivos al perdón y la misericordia ${ }^{25}$

Hubo una corrupción muy generalizada en muchos cargos de justicia, pero afectó menos a los puestos más altos y por otra parte el fenómeno no llegó a extremos que comprometieran la reputación del conjunto del sistema.

Tras la exposición efectuada, habrá quedado patente el utilitarismo imperante en el sistema penal, la actuación discriminatoria y arbitraria de los jueces, lo horrible que podían ser las penas y la voluntad ejemplificadora de las mismas.

La desigualdad jurídica de las personas era un hecho patente en la legislación, en la doctrina y en la práctica judicial. No descubrimos nada nuevo cuando indicamos que nobles y plebeyos recibían un trato bien diferente. Pero también debemos tener en cuenta que en aquella sociedad clientelar quien quedaba fuera del complejo juego de las sociabilidades del Antiguo Régimen no se favorecía de

\footnotetext{
25 Tomás Antonio MANTECÓN MOvelláN. (2011). «Las mujeres ante los tribunales castellanos: acción de justicia y usos de la penalidad en el Antiguo Régimen». Chronica Nova, 37, p. 99-123.
} 
beneficiosas intermediaciones en el caso de ser procesado y quedaba fuera de los canales extrajudiciales de resolución de los conflictos. No es aventurado pensar que ante gitanos, vagabundos y otros excluidos presentó la justicia su cara más terrible.

La proliferación de jurisdicciones obligó a desplegar un complejo entramado institucional, pero debe reconocerse que el conjunto funcionaba con relativa coherencia, pues el rey poseía mecanismos de control sobre cada una de las partes. En todos sitios se aplicaba el derecho real, la justicia se administraba por delegación regia y existían dispositivos para controlar las jurisdicciones que no estaban gobernadas directamente por la corona.

Gracia y justicia, dos caras de la misma moneda, dos facultades que lejos de contradecirse, se complementaban. Mediante penas e indultos, los Habsburgo consiguieron los apoyos necesarios para gobernar una constelación de territorios que una sabia política dinástica y los azares de la fortuna colocaron en sus manos.

¡Y no se olvide, para las gentes de aquella época gobernar era, sobre todo, administrar bien la justicia!

\section{BIBLIOGRAFÍA}

AllozA, Ángel. (2000). La vara quebrada de la justicia: un estudio histórico sobre la delincuencia madrileña entre los siglos XVI y XVII, Madrid: Catarata.

ALMAZAN FERNANDEZ, Ismael. (1992). «Penas corporales y disciplina social en la justicia catalana de los siglos XVI y XVII». Pedralbes, 12, p. 127-148.

Alonso Romero, María Paz. (1985) «Aproximación al estudio de las penas pecuniarias en Castilla (siglos XIII a XVIII)». Anuario de Historia del Derecho Español, 55, p. 9-94.

Bennassar, Bartolomé. (1996). El galeote de Argel. Vida y hechos de Mustafá de SixFours, Barcelona: Edhasa.

Corona Gonzalez, Santos M. (1992). Ilustración y Derecho: Los fiscales del Consejo de Castilla en el siglo XVIII, Madrid: Ministerio para las Administraciones Públicas.

GelaBert GONZALEZ, Juan Eloy. (2002). «Tiempos de Borrasca: notas sobre la violencia política en la Castilla del siglo XVII». En José Ignacio FORTEA, Juan Eloy GELABERT, y Tomás Antonio MANTECON, (eds.). Furor et rabies: violencia, conflicto y marginación en la Edad Moderna, Santander: Universidad de Cantabria, p. 219-238.

GonZALEZ BlanCO, Antonino. (2006). «Horcas, rollos y picotas en la mentalidad del Barroco». En Concepción DE LA PEÑA VELASCO (edit.). En torno al Barroco miradas múltiples. Murcia: Universidad de Murcia, p. 43-56.

Graullera SANZ, Vicente. (2002). «Los marginados en la Corona de Aragón». En José Ignacio ForTEA, Juan Eloy GELABERT, y Tomás Antonio MANTECON, (eds.). Furor et rabies: violencia, conflicto y marginación en la Edad Moderna. Santander, Universidad de Cantabria, p. 285-312.

Hernandez Sobrino, Ángel M. (2010). Los esclavos del Rey. Ciudad Real: Fundación Almadén. 
MARAÑON, Gregorio. (2005). «La vida en galeras en tiempos de Felipe II». Ars Medica. Revista de Humanidades, 4, p. 217-237.

MANTECON Movellan, Tomás Antonio. (2011). «Las mujeres ante los tribunales castellanos: acción de justicia y usos de la penalidad en el Antiguo Régimen». Chronica Nova, 37, p. 99-123.

Perez Garcia, Pablo. (2002). «La criminalización de la sexualidad en la España Moderna». En José Ignacio ForTEA, Juan Eloy GELABERT, y Tomás Antonio MANTECON (eds.). Furor et rabies: violencia, conflicto y marginación en la Edad Moderna. Santander: Universidad de Cantabria, p. 355-402.

PRIOR CABANiLlas, Julián. (2006). La pena de minas: Los forzados de Almadén, 16461699. Ciudad Real: Lozano Comunicación Gráfica.

RAMOS PEREZ, Demetrio (coord.). (1992). Historia General de España y América. Madrid: Rialp, 1992.

SANCHEZ, Rocío; TeStON, Isabel, (2002). «La violencia como factor de expulsión en la Edad Moderna». En José Ignacio ForTEA, Juan Eloy GelaberT, y Tomás Antonio MANTECON (eds.). Furor et rabies: violencia, conflicto y marginación en la Edad Moderna. Santander: Universidad de Cantabria, p. 255-284.

DE SANDOVAL, Bernardino. (1564). Tractado del cuidado que se ha de tener de los presos pobres. Toledo: Miguel Ferrer.

TOMAS Y VALIENTE, Francisco. (1990). «De la administración de justicia al poder judicial». Jornadas sobre el poder judicial en el bicentenario de la Revolución Francesa. Madrid: Ministerio de Justicia.

TOMAS Y VALIENTE, Francisco. (2000). La tortura judicial en España. Barcelona: Crítica. 